\title{
Measuring design investment in firms: conceptual foundations and exploratory UK survey
}

\begin{abstract}
The importance of design to company and national performance has been widely discussed, with a number of studies investigating the value or impact of design on performance. However, none of these studies has measured design investment as an input against which performance can be compared. As yet, there is no established way in which design investment might be measured. Without such a method, we cannot develop a reliable picture, akin to that for R\&D spending, on the impact of design spending on company performance.

This paper presents a conceptual framework for the measurement of design investment and applies this framework in a survey of UK firms. The framework describes design as being part of the creation and commercialization of new products and services. The survey highlights some surprising patterns of design spend in the reported sample and demonstrates the viability of the underpinning framework. A revised framework is proposed that situates design investment in the context of R\&D. The model has implications for policy makers trying to understand the role and scale of design in the private sector, for managers wishing to optimize their design investments and for academics seeking to measure the value of design.
\end{abstract}

\section{Keywords}

Design investment; Valuing design; Design, R\&D and innovation. 


\subsection{Introduction}

Over the past thirty years there has been a broad discussion on how to account for intangibles at the company and national level, both in accounting terms and in models of growth, as a key factor in the innovation process (Corrado et al 2009). Work in this area started with items such as advertising and then moved to include measures of research and development (R\&D) (Hirschey 1982). This reflects ongoing changes in leading economies where knowledge has become progressively more important than labour for many commentators. These changes are especially important for countries such as the United Kingdom (UK) where recent estimates suggest that investment in intangibles as a percentage of GDP is higher than that for tangibles (van Ark at al 2009).

However, "Both firm-level and national income accounting practice have historically treated expenditure on intangible inputs ... as an intermediate expense and not as an investment that is part of GDP" (Corrado et al 2009). This exclusion obscures the role that many of these intangibles may play in innovation and in growth. Unfortunately data for intangibles is in many cases not available. As van Ark et al (2009) commented "Since this is a relatively new research field, statistical offices and other agencies often do not have comprehensive data on various intangible assets, and research is still scarce in most areas."

This paper focuses on design as an intangible asset which is a potentially underrepresented source of long term growth. The strategic importance of design, however defined, has been commented on increasingly over the past decade (Borja de Mozota 2002; Stevens and Moultrie 2008). It has also been recognized that the work to date on Research and Development (R\&D), while important, does not capture all of the investment that is related to product and process innovation (Galindo-Rueda et al 2010). Taking a broad interpretation of design, spanning from technical design to brand and identity design, we aim to define more precisely how design might be measured as an intangible investment at the company level, offering the longer term potential of understanding the impact of this investment on growth. This is not to say that other measures of design performance are not important, but that investment as a specific measure has not been previously defined, as will be discussed in section 1.2. 
There is currently no agreed measure of design investment or a dataset of such spending. A number of large scale efforts have begun to improve the measurement of investment in innovation (e.g. Haskel at al 2009) and a smaller number of studies have begun to include design, attempting to assess how significant investment in design is (Galindo-Rueda et al 2010). These studies use existing datasets, such as the Labour Force Survey for the UK, and work through Standard Industrial Classification Codes and Standard Occupational Classifications to extract the design element of reported figures. Whilst these approaches offer useful insights and good approximations, by necessity it means that such studies must adapt their conceptual understanding of design to fit with these existing data sources and data structures.

The approach taken in this paper is first to develop de novo a conceptual framework by which design investment might be measured, and then apply this framework in an exploratory survey of UK firms. The paper concludes with a revised framework for the measurement of design investment and a discussion on how this new framework relates to the measurement of $R \& D$ as described in the Frascati Manual (OECD 2002).

\subsection{A comparison with measuring investment in Research and Development}

In the late 1980s, the House of Lords Select Committee for Science and Technology (HOL 1987) reported to the UK government on Research and Development (R\&D). They argued that investment in $R \& D$ was insufficient and resources should be focused on improving the situation. Their conclusion was that "as a nation, we are investing too little in $R \& D$ and the situation is getting worse" (HOL 1987). As a result, attention was given to the financial reporting of R\&D expenditure and in the late 1980's, standard accounting procedure SSAP13 was created (Accounting Standards Committee 1989). Other similar standards were created internationally, all based on definitions established in the Frascati Manual (OECD 2002), initially created in 1963. The Frascati manual provides guidance on measurement of R\&D inputs, and "deals exclusively with the measurement of human and financial resources devoted to R\&D."

Whilst the standards on capturing R\&D spend are now well established, this was not always the case. Early attempts to measure R\&D were hindered by its perception as being too "creative and unstructured" to be measured (Kerssens-van-Drongelen 1997, Nixon 1999). Thus, standard management and control techniques were considered inappropriate (Roussel et al 1991). These issues were overcome because there was 
sufficient recognition of R\&D's importance to commit effort to develop a means of measuring it.

In providing the conceptual foundations by which R\&D investment might be measured, there was no attempt to qualify whether this investment was 'good' investment. Indeed, it is only relatively recently that questions have begun to be asked about how the investment is used, not just how much is spent. These new questions are enabled by the earlier work done in conceptualizing and capturing data on how much is invested.

Design is arguably even more 'creative and unstructured' than R\&D and there is also growing recognition of the need for design investment to be better understood:

"It is vital that the financing of design activities, particularly product design, is written into corporate, business and operating plans. The achievement of excellence in design requires funds to be allocated from clearly identified budgets well in advance, to cover properly programmed requirements." (BSI 2002 - BS7000 Pt. 2, p9)

\subsection{Previous work on the value or impact of design}

A number of landmark studies have provided different perspectives on the importance of design for a company. Taken together they provide persuasive evidence that there is a key role for design in creating and sustaining competitiveness. A brief summary of some of the key works is provided below.

Black \& Baker (1987) examined 'design orientation' in around 60 small engineering firms, using 'company growth rate' as a measure of success. However, they avoided any explicit measure of design investment. They claimed that “... successful companies have greater design involvement through the new product development process ..." and that such companies “... are more aware of design as a source of competitive advantage.”

Walsh, Roy et al. (1992) identified a generally positive relationship between design "consciousness" and success in firms, again, avoiding any measures of design input. In their report on the benefits of the Funded Consultancy Scheme, Roy and Potter (1993) state that prior to their work "... there was no information available on the benefits, costs and risks of specific investments in design and product development at the product or project level." 
Gemser (2001) explored the competitiveness of Dutch manufacturing firms that invest in industrial design in comparison with those that do not. This study found a correlation between industrial design intensity and performance, where industrial design intensity is a multiple-item scale based on percentage of new product development (NPD) projects in which professional design expertise was used and number of design awards won.

Hertenstein et al. (2001) also set out to establish the "value of design" in study of 51 companies across 4 sectors. In this case, design orientation was judged by an external expert and this was compared against measures of (business) financial performance. The analysis compared two groups, those judged to have more-effective design and those judged to have less effective design, according to the design experts. Results indicated that effective design is associated with better financial performance. More recently, a similar study found that firms with 'high design effectiveness' are better performing in terms of growth and financial performance (Hertenstein, Platt et al. 2005). Again though, both studies utilized indirect or subjective measure of design effectiveness.

Chiva et al (2009) set out to measure the link between investment in design and firm performance. But, the authors specifically commented that "owing to the difficulties in obtaining design investment data or average expenditure on design during new product development projects ... a self reported approach ... was used." They provided a Likert scale against which respondents scored whether design investment had increased or decreased in the last three years. A similar approach was previously used by Dickson et al (2003). It is also useful to note that Chiva et al do not provide any specific definition for design against which the increase/decrease in investment is judged and that design is situated solely within product development. Thus, in setting out to understand the impact of design investment, they concluded that there was currently no viable means by which this critical construct can be measured.

All of these studies use measures of activity, capability or reputation in order to demonstrate the value of design. In a landmark study, Sentance and Clark (1997) conducted a survey of around 800 manufacturing firms, representing approximately a fifth of the UK's manufacturing industries. Their survey intended to enable the estimation of expenditure on design at a national level. They noted at the time that "the 
main element of design activity is product design that takes place within companies." This reflects their focus in manufacturing, as opposed to other sectors of the UK economy. They formed a categorization of design based essentially around the design professions: Market research; Product development and improvement; Appearance design; Technical design; Process/systems design; Engineering design; and Graphic and brand design. They estimated that UK manufacturers invested around $£ 10 \mathrm{bn}$ on product development and design, in contrast to $€ 7 \mathrm{bn}$ spent on R\&D during the same year. However, the relationship between the types of design in their model is unclear. For example, technical design, process design and engineering design are not linked by a clearly articulated framework. Indeed, in discussing their results, they comment "... it is important to recognize the significant overlap between categories ... Product development and improvement ... embraces many other design activities." They do not provide a detailed explanation of the logic behind this categorization in the paper. In their analysis, they also make an interesting distinction between 'hard' design (technical, process/systems, engineering) and 'soft' design (product appearance, brand, graphics).

In a more recent study, Design France (2002) conducted a survey of 637 manufacturing SMEs (20-500 employees). They asked firms to indicate how much they spend on design per annum, with design split into four categories (product design, packaging design, graphic design and architecture/interior design). Only 17\% of responding firms could isolate these expenses in their accounts. They claimed a typical 'return on investment' of less than 2 years and conclude that "design is not expensive and can pay big, sometimes dramatically."

The most recent effort to assess the size of design investment in the UK is that by Galindo-Rueda et al (2010). This comprehensive study uses existing national level economic datasets to provide an estimate of how much the UK “... employs, spends and invests in architectural and engineering design ..." The starting point is to look at those industries "... where the generation of new designs is one of the main objectives or features of production as implied by the industry description provided in the Standard Industrial Classification (SIC) of economic activities" and occupations in the Standard Occupational Classifications (SOC) that mention design in their description. These can be cross-tabulated to show own-account design activity. According to this method there are 292,465 employees in a design occupation in all industries. The authors also use 
supply/use tables to calculate design output and investment, which leads to an estimate of $£ 27$ billion own-account and $£ 17$ billion purchased design spending. The choice of occupational classifications provides insight into the conceptual framework of 'design' used in the study; including occupations such as electronics engineering, chemical engineers, planning and control engineers.

Most of these studies view design either synonymously with new product development, or as a subset of product development (e.g. industrial design). They all seek to determine the value of design, by comparing an input measure against financial outcome measures. Typically, the input measures are judged subjectively and to date, there is no agreed means by which design investment in firms might be captured. As Galindo-Rueda et al (2010) note; "design leads to lasting valuable property, it becomes crucial to understand how much companies spend on in-house design activities." As with $R \& D$, measuring investment is a prerequisite for later understanding whether this investment is well targeted.

\subsection{Challenges in measuring design investment}

As the review above highlights there are a number of significant difficulties in measuring design investment at the company level. Firstly, the articulation of design used in studies or understood by firms is often ambiguous. There is a substantial challenge in providing an operational definition against which companies of varying sector and size can provide estimates of design spend. Each sector is likely to interpret design in different ways (Walsh 1996). Secondly, there are standards in place for the measurement of investment in $R \& D$, but no such standards apply to design, despite design being more pervasive than R\&D across a wider variety of sectors (Walsh 1996). Thus, companies are not expected to recognize design in their annual company accounts, and as a result, it is not possible to draw any data from these accounts on design spend. Design also spans organizational boundaries, and will find different (or possibly multiple) functional homes even within a single sector (Walsh 1996).

This study aims to address this gap and develop a framework for the measurement of design investment and to evaluate this framework in a pilot survey. The primary objective is to refine a set of constructs or measures that might enable the valid measurement of investment in design. It is not this study's aim to demonstrate the value of design as a result. This distinction is important, and does not mean that exploring the 
value of design is not a longer term goal. However, in order to truly evaluate the value of design, a substantially larger data set would be needed, preferably over a long time period, to enable the impact of those investments to be evaluated.

The next section outlines the development of a conceptual framework of design investment, which forms the basis of an exploratory survey. This is followed by a discussion of the survey methods used, before presentation and discussion of the results.

\subsection{A conceptual framework as a foundation for measuring design investment}

'Design' is notoriously difficult to define. It is applied to an extraordinarily wide range of activity including at one extreme something that could also be called 'engineering' and at another something that could be called 'art' (Lawson 2006). Definitions vary from the highly abstract notions of improving the human condition, through to precise articulations of specific disciplines.

Narrower definitions of design focus on either the act of designing or the outputs as a result of this act. The act of designing is most often viewed either as a process or a problem solving activity (Archer 1965). Lawson (2006) cites Gregory's definition from 1966, where he comments that "the process of design is the same whether it deals with the design of a new oil refinery ... or the writing of Dante's Divine Comedy". The outputs from this process are typically classified as either plans/instructions for subsequent production or as the types of artefacts that ultimately ensue (Dym 1994: p.15). Some definitions are so broad as to encompass almost all human activity. These more broad definitions, whilst in essence correct, are not helpful in pragmatic terms, and are difficult to apply to understand design in practice (Margolin 1989).

The lack of an agreed, concise and operationalisable definition of design is problematic for measurement. In research, the lack of precision makes interpreting potentially useful data difficult. Definitional clarity is thus required to enable financial managers, who typically have little understanding of the subtler definitions of design, to collect data in a consistent and comparable way. 
Two steps have been taken in order to develop such clarity as a basis for the survey reported here. First, based on an initial conceptual framework, a series of six exploratory case studies were conducted to explore alternative ways in which firms might be asked about their investment in design. This step was seen as an important pre-cursor to developing a more detailed questionnaire and aimed to understand how conceptual ideas regarding design might be turned into questions relating to design investment that were both meaningful and could also be completed. These are reported in detail in a previous paper (Moultrie et al 2009). The six case studies were selected to span a wide range of organizations, including: global financial services, high tech start ups, high tech services, small retail services, engineering services, and technical products. Two of the firms were large, with the remainder being SMEs.

In each case, respondents were first asked to describe in their own words the role of design in the firm. Following this initial discussion, participants were presented with a pilot of a proposed "survey instrument" to help explore design spend. The survey instrument served two purposes. First, it enabled the proposed conceptual framework to be explored. Second, it enabled discussion on the challenges in collecting financial information relating to this classification. Participants were asked to comment on the viability of producing financial estimates based on consideration of departmental budgets, resources engaged in design and activities that could be considered as design. All interviews were recorded and transcribed to identify consistent themes and emerging patterns.

As a result of evidence from literature and case studies a four part framework of design investment was developed (Moultrie et al 2009), which forms the basis of the survey instrument used in this study. The framework attempts to walk the tightrope of providing sufficient clarity to enable a company to provide an estimate of investment, without being over-specified and as a result making it difficult for companies across a variety of sectors to interpret and respond appropriately. In developing a framework to enable the measurement of design investment, we are aware that there is no single solution that would suit the needs of every possible firm. There are many ways in which the cake could be cut, and any form of classification will produce boundaries that are not absolute. However, through the case studies, a number of consistent patterns emerged as described below. 
The remainder of this section describes the framework used as the basis for the survey reported in this paper. The operational development of the survey instrument based on this framework is explained in Section 3.

\subsection{Conceptual framework}

Bruce and Bessant (2002) suggested that design is the "purposive application of creativity to all the activities necessary to bring ideas into use either as product (service) or process innovations." This definition encompasses a range of activities that span the creation of new products and services as well as their exploitation in the market place. Thus, in our framework, we first make a distinction between design activity or effort that takes place in creating new products (goods and services) and that which takes place in commercializing those products (Walsh 1996), as illustrated in figure 1.

This basic categorization splitting of design activity reflects the dominant way in which many organizations choose to structure themselves (marketing, engineering/R\&D) and thus also reflects closely the accounting structure of such firms. However, there are also many firms which engage in product development, but where this is the responsibility of the marketing function (e.g. in retail or FMCG firms). Thus, the language has been carefully chosen to not 'name' the department, and instead describe the activity.

Figure 1 about here

For the purposes of data collection, each of these has been further subdivided, to create four categories overall. These subdivisions will now be explained.

\subsection{Design in the creation of new products and services}

When considered from a firm's perspective, many definitions treat design as a component of R\&D. However, as Tarasewich (1996) noted product design does not always depend on R\&D and R\&D does not always lead to new products. Indeed, as R\&D is normally conceptualized (basic research, applied research and experimental development), there is little scope for the inclusion of design. Addressing this issue, Tether (2006) suggests that it may be helpful to distinguish between Research and Design and Development. This distinction is important, as in most organizations there is 
little 'design' activity within the 'research' portion of R\&D. Within 'design and development', it is also possible to distinguish between design that is focused on technical performance and design which has its basis in the arts or in considerations of user experience (Cooper and Press 1995). Dym (1994) suggests that this difference can be considered as an artefact's 'inner and outer' characteristics. In a more traditional sense, this can be seen as the design of function/form or engineering/industrial design (Utterback et al 2006 p66, Moultrie et al 2007). Thus, design and development can be further subdivided:

- Technical design: Resolution of technical issues in the creation of products and services. This might include engineering skills such as mechanical engineering, electrical engineering, software design or the design of IT systems to enable services. It might also include the design of production processes and technologies necessary to deliver services.

- User focused design: Design relating to the experience of the customer and user in the creation of products and services. This might include product aesthetics, ergonomics, interfaces with software, manuals and multi-media to support the experience of the overall service as well as manuals and multi-media to support service delivery.

The distinction between technical and user focused design forms the first part of the framework, allowing respondents to report on design within product development or in a research setting, which to date has been under-represented in discussions on design's impact on company performance.

\subsection{Design as a part of promoting products, services and the company}

Design also plays a role in other aspects of the business, specifically in communication and branding activities (Walsh 1996). These aspects of design are relevant in all firms, including those which do not frequently engage in the development of new products and services. Kotler and Rath (1984) noted the role of design in optimizing customer satisfaction, through their connection with products, environments, information and corporate identity. In the British Standard guide to managing design (BSI 1995: p.9), distinction is made between two aspects of design that are not specifically related to product or service development: 
- Promotion \& customer support: including advertising, promotional literature, packaging, instructions, manuals, exhibitions, presentations, showroom environments, displays in stores, appearance courtesy and knowledge of staff, professionalism of delivery, help-lines, web-help, service workshops etc. This does not include spend on reproducing printed materials or purchasing an advertisement slot.

- Corporate identity and culture: including the physical, operational and human features and values that give the organization its unique personality. This might also include the design of logos, corporate identity, business websites, uniforms, and business color schemes. It is intended to capture design of the whole company identity as distinct from design of individual products and services or their promotion.

Thus, we make a distinction between design activity that applies at a corporate level as compared with design activity that is specific to individual product/service lines. Gorb (1990) similarly made a distinction between the design of products and design of corporate identity.

\subsection{Framework for measuring design investment}

Bringing the elements described above together, figure 2 summarizes the conceptual framework, used as a basis for measuring design investment in companies. This framework was built as a result of evidence from case studies reported in a previous paper (Moultrie et al 2009).

\section{Figure 2 about here}

This framework forms the underpinning basis for the questionnaire used in the survey reported in this paper and has some critical differences to previous attempts in this area. Rather than try to define types of design (such as industrial design or interior design), this framework categorizes the purpose of design use in activities of the company. This avoids having a list which may make sense to design professionals but may be meaningless to production mangers or financial controllers. However, this does not mean we are allowing the respondent free reign to apply their own definition of design, as has been the case in some surveys of design activity. Within the 
questionnaire, examples of the types of design activities that are considered to be part of each category are provided, guiding the respondent on how to answer the question.

It is the intention that the categories described in the framework are mutually exclusive, unlike the approach taken by Sentance \& Clark (1997), who themselves acknowledge that there are fuzzy boundaries between the categories that they measured.

The framework presented was viewed as pragmatic to the case study firms in terms of providing data on design spend (Moultrie et al 2009). However, it is also possible to group the 4 lower level categories in alternative ways to support analysis. Verganti et al (2009) described 'design driven innovation', as being comprised of two complimentary elements: changes in technology and changes in 'meaning'. Here, meaning relates to the emotional, psychological and socio-cultural aspects of consumption. A change in meaning results in a change in the relationship between the consumer and the product or service. These changes are typically delivered through the design of user interfaces, aesthetics, brands, interiors, and experiences. But, truly radical innovation combines these changes in meaning or experience with changes in technology or functionality. This distinction is not unlike the categorization of design as 'hard' and 'soft' used buy Sentance \& Clarke (1997).

Thus, for analysis purposes, design activities of a 'soft' nature can be grouped together, under the single heading of it 'experiential' design (figure 3).

Figure 3 about here

\subsection{Methods}

The primary aim of this work was to develop a new framework for measuring design investment, and if possible to evaluate this proposed approach. To do this, we conducted a telephone survey of design investment in UK firms. All data was collected by a third-party survey specialist research agency, under contract to the research team. The development of the survey instrument was carried out by the research team and the key decisions on the management of the survey were taken by the research team.

Developing the questionnaire involved three steps, prior to administering the full survey: transforming the underpinning framework into a questionnaire for data collection; designing and implementing a pilot survey approach; modifying the survey 
approach and questionnaire as a result of lessons learnt. These steps are described below and this is followed by details regarding the sample generated in the final survey.

\subsection{Initial questionnaire design}

In prior work, there have been only three approaches (that the authors have identified) used for capturing data on design investment at a firm level:

1) Sentence \& Clark (1997): captured spend on 7 'categories' of design (market research, product development and improvement, appearance design, technical design, process/systems design, engineering design and graphic/brand design) as a percentage of turnover in 5 bands $(<1 \%, 1-2.9 \%, 3-4.9 \%, 5-9.9 \%,>10 \%)$

2) UK Community Innovation Survey (CIS 2007): Includes a single question on design expenditure in the section on 'innovation related activities'. The precise wording states "engagement in design activities for the development or implementation of new or improved goods, services and processes. Design activities in the R\&D phase of product development should be excluded". They ask for a single financial value for this one category. The same survey also asks for expenditure on marketing introduction of innovations, which somewhat overlaps with our categorization of design as part of promoting products/services and the firm.

3) Design France: (2002): They asked for the annual spend on design in three bands: $<150 \mathrm{~K} \mathrm{~F}, 150-300 \mathrm{~K} \mathrm{~F},>400 \mathrm{~K} \mathrm{~F}$. They asked for data in four categories: product design, packaging design, graphic design and architecture/interior design.

There are strengths and limitations in each approach. Sentance \& Clark enabled ease of answering (tick boxes rather than numbers), but their categorization is somewhat confused. Banded responses also result in a lack of precision. Design France use a similar approach but with absolute values rather than percentages of turnover, albeit with less 'resolution'. Their four categories of design are also more straightforward. The CIS question attempts to avoid double-accounting, but in so doing the question becomes contradictory. Asking for a single financial value is an improvement on asking for either a ratio or spend-range, does not enable any insight into different forms of design. 
In developing a new survey instrument, we aimed to build on the strengths and weaknesses of these previous approaches. Like the CIS, we seek to gain 'absolute' values for investment. Like the Design France approach we aim to capture data relating to different types of design, but informed by a more robust conceptual basis. It was also important to recognize that we were asking for non-standard financial information (i.e. not currently contained in company accounts). Therefore, questions asked needed to be as unambiguous as possible.

\subsection{Initial pilot survey}

A draft questionnaire was produced and piloted in a small sample of companies. Businesses were initially contacted by telephone to ascertain the most appropriate person to participate in the survey, with the expectation that this would be someone with financial responsibilities within the business. They were given appropriate confidentiality assurances, an explanation of the purpose of the research and their agreement to participate sought, along with their e-mail address. They were then sent the research instrument by e-mail (or in hard copy if they are unable or unwilling to use e-mail). An initial e-mail reminder was sent out if the data was not returned by a preagreed date with a reminder telephone call thereafter. The rationale for this approach was to provide the respondent with the opportunity to locate and check financial information, something that we knew could be important from those who had participated in the initial pilot study, and then enter this information on the research instrument and return it once it had been completed. Unfortunately this approach was not successful. Initial contact was made with 180 businesses and there were 85 followup calls, but, only one full response was achieved.

The research team was aware that in asking for complex financial information, the response rate might be particularly low, and the approach was modified in favor of one that relied far more heavily on telephone interviewing. In addition on-line versions of the questionnaire were developed that could be offered as an alternative to the telephone interview. A telephone survey was viewed to be the best way to improve the response rate, as any respondents could be reassured personally as to the use of the data and any queries regarding the concepts could be immediately clarified. It was also believed that as time-lag between first contact and collection of data would be minimized, this might result in an improved response rate. It is understood that telephone surveys can result in lower quality data, as the person contacted may not 
have a complete view of the company and so can only provide their individual perspective on the company's spending on design. However, this trade off was considered to be worthwhile in order to ensure sufficient returns for analysis.

\subsection{Redesigned survey instrument and approach}

Specific feedback from respondents in the initial approach indicated that they did not feel confident in their estimations and were therefore reluctant to provide their "best guess". To address this, we modified the questionnaire to include a series of options by which the respondent might indicate their level of confidence in their responses. Thus, each estimate of design spend could be given a self-reported precision from "within $£ 1 K$ " to "within $£ 100 K "$ (figure 4). In doing this, we were permitting respondents to make a best-guess, but were able to check the respondents' level of confidence in making this guess. This was inspired by the Sentance \& Clark (1997) approach (enabling a range to be specified).

As this survey was administered via telephone, interviewers had a standardized script to follow, in line with the questionnaire itself. A copy of the survey tool is provided in Appendix 1.

Having gained an initial estimate for investment (in-house and outsourced), for each sub-category of design, respondents were asked to judge the precision with which they feel that they could make this estimate. Figure 4 illustrates the 'structure' of each question related to design spend and shows how it might appear if respondents were completing this survey on paper or online.

\section{Figure 4 about here}

Respondents were asked to provide estimates for each of the four sub-categories of design in turn, both in-house and out-sourced. An estimate of the firm's total design investment could then be ascertained by summing these elements.

This approach aimed for a manageable balance between providing no (or a broad) definition for design and having a highly detailed definition of design with multiple categories and levels, which would not be appropriate in all firms. This approach was believed to provide the best trade-off between clarity in what is being asked and the ability for companies of varying size and sector to provide an estimate. 
A number of other questions were asked as control variables, these included the number of designers employed in the company, R\&D spending in the last financial year, turnover and number of employees overall.

\subsection{Sample in final survey}

The survey was conducted in 2009, asking firms for data in the calendar year 2008. Overall, 3,334 attempts were made to contact companies with 824 successful contacts leading to 428 responses, a response rate of $12.8 \%$. Of these responses 358 were complete and useable. 61 Responses were not used where company turnover was not available. Attempts were made to backfill company turnover data via Companies House filings and by re-contacting the companies. However, it was not possible to complete all companies to the point where they could be included in the final analysis.

The sample was designed to span the composition of the population of UK enterprises, albeit with an over representation of manufacturing firms. None of the responding firms were in the public sector. $19 \%$ of respondents were from firms with less than 10 employees, 54\% from firms with between 10 and 59 employees, 20\% from firms with 50-249 employees and the remaining 5\% from firms with more than 250 employees. Four specific sectors account for the majority of the 358 usable responses; manufacturing ( $23 \%$ of the sample), construction (15\% of the sample), wholesale and retail (19\% of the sample) and 'other business services' (SIC codes 72 and 74, 21\% of the sample). A breakdown of the specific SIC codes included within each of these categories is included in table 1 . SIC code data is available only at a two digit level, given the comparatively small nature of the sample.

Six responses were not used, where the value for design investment indicated a design spend greater than turnover. We applied this simple rule, to ensure that the results analyzed were as robust as possible. This is not to say that there are no circumstances where design investment might be greater than turnover, for example when a firm is investing more than they earn as a deliberate strategy. Without following up with individual companies however, we could not be certain that this was the case. A further three were excluded because the ratio of design investment/ turnover was greater than 0.5 and thus greater than the majority of firms in the sample.

Table 1 about here 


\subsection{Results: UK company investment in design}

The survey outcomes are not the primary purpose of this paper, but they provide some interesting insights into the role of design in firms. Thus, the high level results are reported here, followed by a discussion regarding the structure of the questionnaire and the viability of the conceptual framework to capture design investment.

The total reported investment in design for the sample was $£ 92$ million. The total turnover of the companies in the sample was approximately $£ 4.4$ billion, implying an average 'intensity' of design investment of $2.1 \%$ of turnover over the whole sample. The average design spend as a percentage of turnover for the companies was just over $4 \%$, higher than the sample 'intensity' due to significant skew in the data; just over $15 \%$ of companies reported no design spend and 37\% reported a spend between zero and $£ 10 \mathrm{~K}$. This high skew is evident in the standard deviations for the results on design spend (Table 2).

\section{Table 2 about here}

For the four 'types' of design investment (technical, user-focused, corporate ID and promotional), technical design investment dominates, with $81 \%$ of the total reported design spend falling into this category. In a similar way the vast majority of design investment is in-house, with approximately $86 \%$ of reported design expenditure held within the companies.

There is a difference in the overall pattern of investment in design between the different categories. For the whole sample, the average investment in technical design (At $£ 211 \mathrm{~K}$ ), is around ten times the amount invested in the design of promotional materials and 20 times the amount invested in either the design of the corporate ID or the design of materials related to the direct user experience of new products or services (table 3). The scale of spending between these categories indicates that the inclusion of technical design investment is essential in order that the total design spend might be calculated. For the whole sample, technical design has the highest average investment by a factor of 7 compared to promotional design, followed by user focused design and finally identity design. 


\subsection{Design investment by sector}

Manufacturing dominates in investment on technical design, with an average investment of $£ 698 \mathrm{~K}$ compared to the next highest average of $£ 171 \mathrm{~K}$ in wholesale and retail. The varied nature of companies responding is highlighted by the fact that 205 companies out of 358 reported zero technical design investment (57\%). A similar skew is seen for user-focused design, with 243 companies reporting zero investment in this category.

For the design of promotional materials, the sector with the highest average investment was wholesale at $£ 44 \mathrm{~K}$. In contrast to technical and user-focused design, only 120 companies reported zero investment in this category. As a more traditionally understood design function this may not be surprising, but it does indicate where design is thought to operate. Similarly, retail and wholesale invest the most in developing their corporate identity, although the differences between sectors are less significant. Identity design was the second most reported category with 197 companies reporting some investment. This demonstrates the perceived importance of brand building in wholesale sectors as a key mode of differentiation.

\section{Table 3 about here}

If we compare results as a 'percentage of turnover', a similar but subtly different story emerges (Table 4). Where manufacturing dominates in absolute terms, it is second to "other business services" in relative terms (2.3\% compared to $3.0 \%)$. This category includes inter-alia product development consultancies and marketing service providers and so there may be a significant focus on both technical and promotional design. However, in this relative sense it is interesting to note how manufacturing, which led in absolute terms, is not the leader in any of the categories of design spend as a percentage of turnover.

Technical design also plays a strong role in retail and wholesale, which is significant as it demonstrates that technical design investment is not just related to physical products, and is also important in businesses that might be regarded as service based. The other business services sector has the highest overall investment in design as a percentage of turnover across all categories. 
In the experiential categories, promotional design is dominant, and especially in the service sectors. These results indicate that the relative need for promotion is highest in businesses offering direct services, whereas it might be expected that as a competitive differentiator it would be most required in wholesale. In both cases, this suggests that relative investment in promotion is higher in service sectors compared with firms producing physical goods.

\section{Table 4 about here}

\subsection{In house or outsourced}

Another way to examine this data is to compare design investment that is conducted 'in house' and design investment that is outsourced. Figure 5 illustrates the relative design spend in these different areas. The pattern of outsourcing between technical and experiential design investment is very different. The ratio of in-house to outsourced investment for technical design is roughly 10:1. In contrast, the ratio for experiential design investment is roughly $2: 1$. Thus, a firm is much more likely to retain a technical design capability, but views experiential design as a less critical core competence and as a result it can be outsourced. This matches conclusions made by Sentance and Clark who suggest that "for 'hard' design, the optimum mix is biased towards in-house, whereas the reverse is true for the more creative design [soft] components" $(1997, \mathrm{p} 14)$

\section{Figure 5 about here}

Figure 6 presents data for an 'average' firm from the sample. Here, an 'average' firm might invest $£ 211,000$ in technical design, $£ 21,000$ of which is outsourced (figure 4). From the data provided, an 'average' company has a turnover of $£ 12 \mathrm{M}$ and employs 72 people, 3 of whom are designers. Average R\&D spend is $£ 161,000$ per annum.

\section{Figure 6 about here}

\subsection{Variation in investment by company size}

An interesting question for design investment, (as well as R\&D or other types of investment), is how these change as companies grow and more specifically what types of design are utilized. Table 5 shows how the average design spend as a percentage of turnover varies for companies grouped into four size bands across the four types of design. For example, for companies with more than 250 employees technical design is 
dominant in terms of intensity, followed by promotional design, identity design and finally user-focused design.

The relative size of promotional investment changes significantly from the largest to the smallest companies. For companies with more than 250 employees, promotional design relative to technical design is 0.16 , and this rises to 0.87 for companies with between 1 and 9 employees. This would suggest that for small (and possibly young) firms, promotional design investment is as important as technical design investment.

\section{Table 5 about here}

\subsection{Companies reporting zero design investment}

The overall percentage of companies reporting zero investment in any category was just over $15 \%$. This number may include a combination of firms who have not engaged yet with design, firms which did not have data available and also firms which misinterpreted the survey.

However, the percentage of companies reporting zero investment in each category varied quite significantly. The category with the highest reporting of zero investment was user focused design (68\%), followed by technical design (58\%), identity design (45\%) and finally promotional design (34\%). This suggests companies across the economy have a common need for promotional design, with a similar need in a weaker sense for identity design.

We can also compare whether companies have either a technical or user-focused design investment (i.e. design aligned to product development), contrasted to whether they have a promotional or identity investment. Figure 7 shows the level of overlap between these categories, with $43 \%$ of companies reporting a technical or user focused design investment as well as a promotional or identity design investment.

This confirms the need for the framework to contain an inclusive set of categories, and not just view design as a part of product development. There are many firms which invest in promotional or identity design, but not technical or user-focused design (36\%). The reverse is not the case, as very few companies that have a technical or user investment have at the same time no reported promotional or identity spend (5.6\%). 


\subsection{Self reported precision of estimates}

In the questionnaire, respondents were asked to self report on the precision of their estimates. They were provided with 4 options; within $£ 1 \mathrm{~K}$, within $£ 10 \mathrm{~K}$, within $50 \mathrm{~K}$ and within $£ 100 \mathrm{~K}$. These bands were established prior to receiving the data and as a result, for firms reporting less than $£ 10 \mathrm{~K}$ spend in any category, the confidence levels can be misleading. For many firms, the actual spend is substantially less than $£ 1 \mathrm{~K}$ per annum in a category. For example, 24 firms spent less than $£ 1 \mathrm{~K}$, but more than zero on outsourcing identity design.

Table 6 presents data regarding to self reported precision of estimates. Here, for each category of spend, the average investment within a 'precision band' is noted, along with the number of firms to which this applies. So, for in-house technical design, 63 firms reported a precision of estimate to within $£ 1 \mathrm{~K}$, and their combined average investment was $£ 35,000$. In contrast, 11 firms reported a precision of estimate to within $£ 100 \mathrm{~K}$, but with a combined average investment of over $£ 4 \mathrm{M}$. In order to interpret the estimates of precision, it is also necessary to see the average investment to which this applies.

Firms appear to have the highest belief in their estimates for 'technical design' and especially for in-house investment. The lowest level of precision is for out-sourced identity design; 24 firms estimated a precision of 'within $£ 10 \mathrm{~K}$ ', with a combined average investment of $£ 25,000$. Thus, they are effectively saying that their investment lies somewhere between $£ 15,000$ and $£ 35,000$.

It is perhaps unsurprising that respondents felt more able to estimate their investment in technical design. The experiential aspects of design are investments that have not traditionally measured, and thus do not fall easily into existing accounting methods.

\section{Table 6 about here}

\subsection{Challenges of capturing data}

All respondents were asked whether they found it difficult to provide data. 100 respondents replied that they did, whilst 249 that they did not find it difficult. Those that did find it hard were asked to explain why, with explanations falling into six categories:

- It is 'just difficult' to do, but I will provide my best estimates (33 respondents) 
- The data isn't structured this way in the company accounts, therefore difficult to get hold of (11 respondents)

- I only have data for my part of the business, not other functions (11 respondents)

- The questions are vague or not clear (4 respondents)

- The categorisation doesn't work for my business (3 respondents)

- The numbers are spread across a number of different business functions, therefore difficult ( 2 respondents)

Few respondents challenged the logic or structure of the approach. Indeed, one commented "worded very well"! The most significant challenges relate to the boundary spanning nature of design, which is not reflected in accounting standards and the need for data to be collected from across the whole business. Thus, it is unlikely (especially in a larger firm) that there will be any single person with a grasp of all aspects of design investment.

These observations are important, as there is no doubt that any conceptualisation of design for the purposes of measurement has the potential to be contentious. Indeed, as observed in section 2.1, no single categorisation will satisfy all possible interpretations of design. However, we have demonstrated that this approach is broadly in line with the understanding of design in many businesses.

\subsection{Conclusions}

This study has sought to develop a conceptual framework that might enable the measurement of design investment. This framework has been evaluated through a UK based survey of firms of varying size and sector. The survey has demonstrated the basic viability of the framework, and also presents some interesting insights regarding the nature of design investment in firms.

Following a brief summary of some of the key findings, there is a short discussion on the relationship between R\&D and design and the challenges this poses for measurement. The paper then concludes with a revised framework containing minor modifications, 
made in light of the survey responses. Finally, the implications and limitations of this work will be briefly discussed along with opportunities for further work.

\subsection{Summary of key findings}

Measuring investment in design is acknowledged to be difficult, and this study has set out to both demonstrate that it is possible and to propose a scheme by which this goal might be achieved. In so doing, we have also captured some provisional data that provides some interesting insights into patterns of design investment in different sectors.

Across a sample of 358 firms that provided usable data, investment in design is highly skewed. Indeed a near normal distribution can be achieved by taking the log values for investment. Thus, the majority of firms invest little and conversely a minority of firms invests substantially.

Significantly, the majority of firms were able to provide data which they believed to be reliable. Many respondents found it difficult to provide data, due to availability of data within the firm. However, they found the categorization used to capture data to be understandable and appropriate.

On average, investment in design is around $4 \%$ of turnover, with $2 \%$ relating to technical design in creating new products and services. The remaining $2 \%$ covers experiential design, encompassing both the creation and promotion of new products and services. By example, it is possible to consider the design effort given to a new consumer electronic device. Engineering designers will make a device that is functional and that performs as expected. Interface designers and industrial designers are the interface between the technology on the inside and the user experience. Packaging and promotions are tackled by designers with expertise in graphics. Our overall experience is influenced by the design of the media used to communicate including print and online and the company's brand values will also make a strong impact.

There is a much greater tendency to outsource experiential design (e.g. graphics, industrial design, branding, interface design) at a ratio of 2:1 in-house to outsourced, than there is to outsource technical design (e.g. engineering design, software design, electronic design or optical design) at a ratio of 10:1. This is perhaps indicative of the core capabilities that firms believe they need in order to remain competitive. In other 
words, experiential design is perhaps viewed less as a core competence than technical design.

$81 \%$ of all design investment is in 'technical design', focused on performance and functionality of new products and services. Of the responding firms, 33.4\% engage in technical design, but only $8.6 \%$ indicated that they claim R\&D tax credits. This provides compelling evidence that existing frameworks for measuring $R \& D$ might be missing a portion of important activity. This will be further discussed below.

\subsection{Measuring design and R\&D investment}

Design and $R \& D$ have a symbiotic relationship (Walsh 1996). But, it is widely acknowledged that "R\&D as measured does not capture all of this [process and product] investment" (Galindo-Rueda et al 2010). It is also clear that design only partly overlaps with $R \& D$, as seen from the responses in this survey.

In our survey, only $8.6 \%$ of companies in the sample indicated that they claim $R \& D$ tax credits, whereas 33.4\% report internal technical design investment in the development of products and services. This may indicate either that companies who could claim R\&D tax credits are not, or that technical design is reliably distinct from R\&D spending. Given that four times as many companies indicate a technical design investment to those who claim R\&D tax credits this remains an important open question. However, technical design investment is highly correlated to $R \& D$ spend (both significant at the 0.01 level for Pearson correlation test), implying that there is a strong link between what is being reported as spend even if companies are not claiming tax credits for R\&D work. To remove the effect of company size, we can also make comparisons of investment with respect to turnover. Technical design spend as a percentage of turnover is correlated with $R \& D$ spend as a percentage of turnover $(R=0.352, p<0.01)$. Experiential design as a percentage of turnover is also correlated with $R \& D$ spend as a percentage of turnover $(\mathrm{R}=0.128, \mathrm{p}<0.05)$.

As a comparison, the Community Innovation Survey (CIS, 2007) asked whether companies had "Expenditure on design functions for the development or implementation of new or improved goods, services and processes" specifically excluding design investment in support of $R \& D$. The percentage of all companies indicating this kind of spend in the period 2004 - 2006 was 17\%. This is much lower than any of the reported percentages for design investment in this study. In part, this 
might be explained by how this is worded in CIS and the attempt to position it relative to $R \& D$ and innovation expenditure. It also highlights the difficulty in clarifying the interface between design, $\mathrm{R} \& \mathrm{D}$ and innovation.

In a DTI (2005) think piece, Tether plots a tentative relationship between R\&D investment and Design investment, drawing on evidence from the UK CIS and the Sentance \& Clark study. He plots 'types' of firms, based on this initial mapping. The axes are based on percentages of expenditure with respect to sales, with design expenditure running from 1\%-10\% (based on the survey conducted by Sentance \& Clark) and R\&D investment running from $0.1 \%$ to $10 \%$ (based on $R \& D$ expenditure from $0 N S$ ). Based on data from our survey, we are able to refine this visualization. Figure 8 shows a categorization of firms based on these two dimensions. Dots representing firms in the survey are visible. The majority of firms spend under $10 \%$ on both R\&D and design. However, there are some who spend more in both dimensions. Interestingly, the majority of firms have a greater design investment than $R \& D$ investment. We might distinguish between those firms that are design leaders (in terms of investment), those that are technology leaders and those that provide undifferentiated offerings.

\section{Figure 8 about here}

The apparent importance of design in comparison to R\&D suggests that design is a 'poor cousin' in the existing measurement standards. The challenge of fitting design within established frameworks is not new. In 1992, Walsh noted that "design is a borderline case between R\&D and other industrial activities and OECD member states are asked to divide their data on design, some to be included in R\&D and the rest excluded". Sentance \& Clark (1997) as a result of their exploration of design investment noted that "our design measures clearly capture some activity which is covered by other measures of innovation activity ... However, in many industries "design" embraces a wider range of activities than R\&D." In an attempt to deal with this fuzziness, Corrado et al (2009) create a new 'type' of R\&D, called 'non-scientific R\&D', which includes "revenues from the non-scientific R\&D industry ... the costs of developing new motion picture films and other forms of entertainment, investment in new designs and ... spending for new product development by financial service firms." They note that investment in this type of non-scientific R\&D is as large as spending on scientific R\&D. 
The standard protocols for measuring R\&D is the Frascati (OECD 2002) Manual, which views design extremely narrowly, as the creation of plans plans or drawings necessary for the conceptualization activities within R\&D. Within Frascati, it is noted that in addition to R\&D, there are many 'other innovation activities' such as industrial design, production start-up and marketing for new or improved products (OECD 2002, para 22, para 79), which are described in detail in the Oslo Manual (OECD 1997) for measuring innovation. The explicit criteria for activities being included within the umbrella of R\&D is the presence of both novelty and the resolution of technological uncertainty (OECD 2002, para 84). However, it is recognized that there are fuzzy boundaries between activities that can and cannot be included. A problem arises with activities such as tooling-up and design and prototype construction which are at the borderline and may contain a component of R\&D, if they pass the test described above (OECD 2002, para 110).

Given that the Frascati manual represents the 'standard' approach to measuring R\&D, the proposed framework for measuring design presents a challenge, as measuring design in this way may result in 'double accounting'. It seems that design and R\&D are intertwined and thus it is difficult to envisage separating them for the purposes of measurement. As a pragmatic response, it would seem a sensible option would be measure both independently and to then ask respondents to judge the extent to which there is overlap.

\subsection{Revised conceptual framework}

We have seen that the conceptual framework provides a foundation upon which a measure of design investment might be made, but there are inherent challenges to collecting the data. These challenges relate to how this conceptualization is embodied in a data collection instrument, and specifically the phrasing of survey questions. A further challenge is presented as, unlike $R \& D$, design rarely falls under a single organizational function. Design inherently crosses the boundaries between marketing and technology.

To address these concerns, one option is to position the conceptual framework within a more traditionally understood organizational structure, and to relate this to the broader concept of R\&D. Figure 9 presents a revised framework, where design is situated within functional disciplines of marketing and $R \& D$, and this positioning is contrasted against 
the broader concept of innovation. It can be seen that design, marketing and $R \& D$ are at the same time distinct, but also deeply intertwined.

\section{Figure 9 about here}

Of course, not all firms are structured in this way. Drawing on the discussion in 5.2, technical design may, or may not be considered part of experimental development, as might user focused design. In some organizations, and especially service based firms, it is quite possible for the entire responsibility for design to fall within Marketing, especially where there is no recognized $R \& D$ department. Thus, design as a set of activities and skills sits in the interface between these two functions.

Looking at the design constructs, it is also possible that these might be further generalized. Data on promotional design and corporate identity design suggests that as two small categories, these might in practice be treated as a single category. The 'technical design' component might be viewed as relating to functional/performance design issues. Likewise, the user-focused and promotion/identity design components might possibly also be grouped under 'experiential'. By using this terminology, it might make the framework more generalizable to non-manufacturing sectors or service sectors.

\subsection{Implications for theory and management}

The most significant theoretical contribution from this work is the building of a conceptual framework that aims to enable firms to report their investment in design. We have demonstrated that the categorization developed is both conceptually valid but also viable and that estimates of design investment can be provided by companies. This is a significant output, and is a first step towards assessing the importance of design to a company in financial terms; in so doing, it potentially opens up a new area of research.

The framework is a subtle, but important contribution for a number of reasons. Firstly, if we take technical design investment alone, it has been shown that this type of spend is often substantial, even in firms which are not active in R\&D. Thus, current measures of R\&D activity do not sufficiently account for this technical design activity.

For true design led innovation, there should be investment in both technical and experiential aspects of design. Interestingly, experiential design investment is an order of magnitude smaller than its counterpart. Companies spend comparatively little in 
areas more traditionally thought of as industrial design, graphics, branding etc. Again, this has potential significance, as it is through investment in these areas that differentiation is often delivered. It may be that there is a disproportionate impact of this small investment. Further work should explore the extent to which the comparatively small investment in the experiential aspects of design has a disproportionate effect, or leverage, on the financial results of the firm. One approach would be to follow a panel of firms over multiple years, to capture data on investment in comparison with measures of company growth in order to explore the relationship between the two.

At the same time, the framework and the results of the survey highlight the continuing issues with the definitional overlaps between R\&D and design, and take a first step at providing clarity on the interfaces between each activity. Finally, this approach, and the ability to be more precise about the nature of the relationship between R\&D and design, may challenge the R\&D led analysis of growth at the company level. It remains an open question across company types and sizes whether R\&D spending or design spending is more strongly linked to future company performance.

For managers, the results may challenge their perception of the role of design within their organization and will give them a first pass analysis of whether they have the correct balance of design spending across the four categories of technical, user focused, promotional and identity design spending. Managers in small firms (1 - 9 employees) may need to have an equal balance of technical and promotional design activities, and such guidance will be of particular interest to new companies in not ignoring the broad range of design that they may need to deploy in order to be successful.

If the levels of design investment reported are reliable, then this poses methodological problems for future work to evaluate the value of design. With investment levels in experiential design at $2 \%$ turnover (or less), then demonstrating a differential impact of this spend will be difficult. It is likely that there will be many more dominant factors influencing success. But, if design can be measured with sufficient precision, then it may be that this very small investment has a truly disproportionate impact on overall success. It is hoped over time that such measurements, following a similar path to the measurement of R\&D investment, will become standard and that anecdote and belief regarding the value of design might be replaced by reliable evidence. 


\subsection{Further work}

Recognizing that this is a small sample, it would clearly be beneficial to extent this initial survey to create a larger data set. A larger data set would enable greater detail to be developed regarding individual sectors at a finer level of precision than in the study reported. A larger data set would also enable a first attempt at linking design investment with company performance, which is the holy grail of academic studies in this domain.

\section{Acknowledgements}

This work was carried out as part of the Design Scoreboard project funded by the Design for the $21^{\text {st }}$ Century initiative of the Arts and Humanities Research Council (AHRC) and the Engineering and Physical Sciences Research Council (EPSRC). The Design Council of the UK also provided financial support for the survey as well as valuable input and commentary throughout.

\section{References}

Accounting Standards Committee. (1989) Statement of Standard Accounting Practice 13: Accounting for research and development. London: The institute of chartered accountants in England and Wales.

Archer, L. B. (1965). Systematic method for designers, Council for Industrial Design.

Black, C. D. and M. J. Baker (1987). "Success through design." Design Studies 8(4): 207 - 216.

Borja de Mozota, B. (2002). "Design and competitive edge: a model for management excellence in European SMEs." Design Management Journal 2(1): pp. 88 - 104.

Bruce, M. and J. Bessant (2002). Design in Business: Strategic Innovation Through Design. New York, Financial Times/Prentice Hall.

BSI (1995). BS 7000-10:1995 Design Management Systems - Part 2. London, British Standards Institute.

Chiva R, Algere J, (2009), Investment in design and firm performance: the mediating role of design management, Journal of Product Innovation Management, V26, pp424-400

CIS, (2007), The CIS questionnaire and other details can be found online at http://www.dius.gov.uk/science/science_and_innovation_analysis/cis.

Cooper, R. and M. Press (1995). The design agenda: a guide to successful design management. Chichester, Wiley 
Corrado C, Hulten C, Sichel D, (2009), Intangible capital and US economic growth, Review of Income and Wealth, Series 55 Number 3, pp661-685

Design France, (2002), Les pratiques du design en PMI, Rapport D'étude, Novembre, Ministère de l'Economie des Finances de l'industrie

Dickson P, Schneier W, Lawrence P, Hytry R, (2003), Managing design in small high-growth companies, Journal of Product Innovation Management, Vol. 12 No. 5, pp406-414

DTI: Department of Trade and Industry, (2005), Think piece: The Role of Design in Business Performance, CRIC, University of Manchester

Dym, C. (1994). Engineering Design: a synthesis of views, Cambridge University Press.

Galindo-Rueda F, Haskel J, Pesole A, (2010), How much does the UK employ spend and invest in design? Working Paper, Imperial College 2010/05

Gemser, G. and M. Leenders (2001). "How integrating industrial design in the product development process impacts on company performance." Journal of Product Innovation Management 18: 28 - 38.

Gorb, P. (1990). Design Management. London, Architecture, Design and Technology Press.

Haskel J, Clayton T, Goodridge P, et al, (2009), Innovation, knowledge spending and productivity growth in the UK: interim report for NESTA 'Innovation Index' project, Innovation, knowledge spending and productivity growth in the UK: interim report for NESTA 'Innovation Index' project, 2010/02, Imperial College Business School

Hertenstein, J., M. Platt, et al. (2001). "Valuing design: enhancing corporate performance through design effectiveness." Design Management Journal Summer 2001: 10 - 19.

Hertenstein, J. H., M. B. Platt, et al. (2005). "The impact of industrial design effectiveness on corporate financial performance." Journal of Product Innovation Management 22(1): 3 - 21.

Hirschey M, (1982), Intangible capital aspects of advertising and R\&D expenditures, The Journal of Industrial Economics, Vol. 30 No. 4, pp375-390

House of Lords (HOL) Select Committee on Science and Technology. (1987). Fiscal incentives for R\&D spending. London: HMSO.

Kerssens-van-Drongelen, I. C., \& Cooke, A. (1997). Design principles for the development of measurement systems for research and development processes. R\&D Management, 27(4), 345 357.

Kotler, P., Rath, A., 1984. Design: A powerful but neglected strategic tool. Journal of Business Strategy, 5(2), pp.16-21.

Lawson, B. (2006). How designers think: The design process demystified. Oxford, Elsevier.

Margolin, V. (1989). Design discourse: history, theory, criticism, University of Chicago Press. 
Moultrie J, Clarkson P J, Probert D R, (2007), Development of a design audit tool, Journal of Product Innovation Management, Vol. 24 No. 4

Moultrie, J., Livesey, T. F., Malvido, C., Beltagui, A., Pawar, K., and Riedel, J. (2009), Design funding in firms: a conceptual model of the role of design in industry, Design Management Journal, 5. pp. 68-82.

Nixon B, (1999), Evaluating design performance, International Journal of Technology Management, V. 17 No. 7/8 pp 814-829

OECD (2002), Frascati Manual 2002: Proposed Standard Practice for Surveys on Research and Experimental Development, The Measurement of Scientific and Technological Activities, OECD Publishing.

OECD/Statistical Office of the European Communities, Luxembourg (2005), Oslo Manual: Guidelines for Collecting and Interpreting Innovation Data, 3rd Edition, The Measurement of Scientific and Technological Activities, OECD Publishing.

Roussel, P. A., Saad, K. N., \& Erickson, T. J. (1991). Third Generation R\&D: Managing the Link to Corporate Strategy. Boston, MA: Harvard Business School Press.

Roy, R. and S. Potter (1993). "The commercial impacts of investment in design." Design Studies 14(2): 171 - 193.

Sentance, A. and J. Clark (1997). The contribution of design to the UK economy. London, Design Council.

Stevens, J. and J. Moultrie (2008). "How is design strategic?" Design Principles and Practices: An International Journal 2(3): pp. 51 - 60.

Tarasewich, P. (1996). "Design for success." Industrial Management March/April: 28 - 32.

Tether, B. S. (2006). Design in innovation: Coming out from the shadow of R\&D: An analysis of the UK Innovation Survey of 2005, Manchester Business School.

Utterback J, Vedin B-A, Alvarez E, Ekman S, Sanderson S W, Tether B, Verganti R, (2006), Design inspired innovation, World Scientific Publishing Co., Singapore

van Ark B, Hao J X, Corrado C, Hulten C, (2009), Measuring intangible capital and its contribution to economic growth, EIB Papers, Vol. 14 No. 1, pp62-92

Verganti R, (2008), Design meanings and radical innovation: a meta-model and research agenda, Journal of Product Innovation Management, Vol. 25 No. 5, pp436-456

Walsh, V., R. Roy, et al. (1992). Winning by Design: technology, product design and international competitiveness. Oxford, Blackwell Business.

Walsh V, (1996), Design innovation and the boundaries of the firm, Research Policy, V 25 pp509-529 
Design investment

Design in the creation of new products and services
Design in the commercialisation, promotion and delivery of products and services or the overall business

Figure 1: High level categorization of design

Design investment

Design in the creation of new products and services

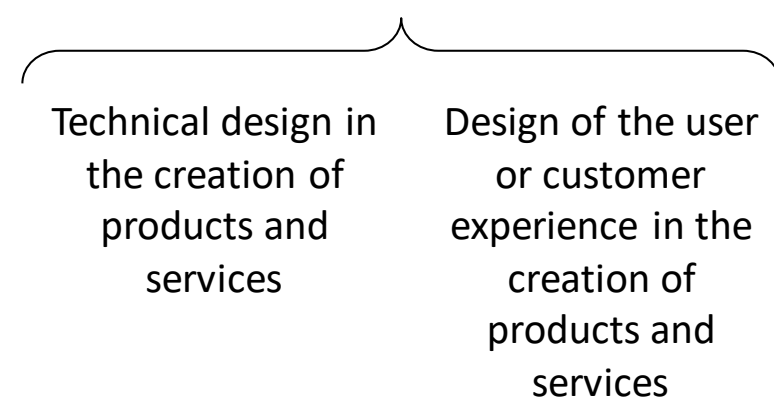

Design in the commercialisation, promotion and delivery of products and services or the overall business

$\begin{array}{cc}\begin{array}{c}\text { Design in the } \\ \text { communication, } \\ \text { promotion and } \\ \text { delivery of } \\ \text { products and } \\ \text { services }\end{array} & \begin{array}{c}\text { comm in the } \\ \text { and promotion, } \\ \text { the corporate } \\ \text { identity }\end{array}\end{array}$

Figure 2: A conceptual framework for capturing design investment

\section{Design investment}

Design in the creation of new products and services

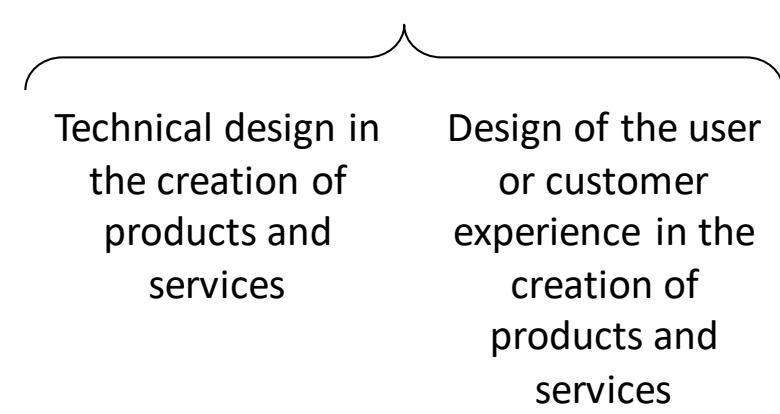

Design in the commercialisation, promotion and delivery of products and services or the overall business

$\begin{array}{cc}\begin{array}{c}\text { Design in the } \\ \text { communication, } \\ \text { promotion and } \\ \text { creation, } \\ \text { delivery of } \\ \text { communication } \\ \text { and promotion of } \\ \text { the corporate } \\ \text { services }\end{array} & \begin{array}{c}\text { identity } \\ \text { tents }\end{array}\end{array}$

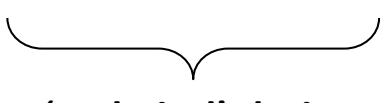

'Technical' design
'Experiential' design 
Figure 3: Conceptual and analytical framework

\begin{tabular}{|c|c|c|c|c|c|c|}
\hline \multirow{2}{*}{\multicolumn{2}{|c|}{ Estimate of design spend }} & \multicolumn{5}{|c|}{$\begin{array}{l}\text { Precision of estimate (please tick as appropriate, to } \\
\text { indicate the relative precision of your estimate) }\end{array}$} \\
\hline & & \multirow{2}{*}{$\begin{array}{l}\text { Within } \\
£ 1 \mathrm{~K} \\
\square\end{array}$} & \multirow{2}{*}{$\begin{array}{l}\text { Within } \\
\text { f10K } \\
\square\end{array}$} & \multirow{2}{*}{$\begin{array}{l}\text { Within } \\
\text { f50K } \\
\square\end{array}$} & \multirow{2}{*}{$\begin{array}{l}\text { Within } \\
\text { f100K } \\
\square\end{array}$} & \multirow{2}{*}{$\begin{array}{l}\text { Can't } \\
\text { Estimate } \\
\square\end{array}$} \\
\hline In House & fK & & & & & \\
\hline Outsourced & fK & $\square$ & $\square$ & $\square$ & $\square$ & $\square$ \\
\hline
\end{tabular}

Figure 4: Structure of the design spending question 


\begin{tabular}{|c|c|c|c|c|c|}
\hline Division & $\begin{array}{l}\text { Industry } \\
\text { description }\end{array}$ & $\begin{array}{l}\text { SIC Codes (2003) included within } \\
\text { sample }\end{array}$ & $\begin{array}{l}\text { Population } \\
\text { of firms in } \\
\text { the UK } \\
\text { economy }\end{array}$ & $\begin{array}{l}\text { Population } \\
\text { of firms in } \\
\text { this Survey }\end{array}$ & $\begin{array}{l}\text { No. } \\
\text { firms } \\
\text { in } \\
\text { survey }\end{array}$ \\
\hline$A, B$ & $\begin{array}{l}\text { Agriculture, } \\
\text { Hunting and } \\
\text { Forestry; Fishing }\end{array}$ & NA & $4.0 \%$ & $0.0 \%$ & 0 \\
\hline$C, E$ & $\begin{array}{l}\text { Mining \& } \\
\text { Quarrying; } \\
\text { Electricity, Gas \& } \\
\text { Water Supply }\end{array}$ & $\begin{array}{l}40 \text { Electricity, gas, steam and hot } \\
\text { water supply }\end{array}$ & $0.2 \%$ & $0.3 \%$ & 2 \\
\hline D & Manufacturing & $\begin{array}{l}15 \text { Manufacturing of food products } \\
\text { and beverages } \\
22 \text { Publishing, printing and } \\
\text { reproduction of recorded material } \\
24 \text { Manufacture of chemicals and } \\
\text { chemical products } \\
29 \text { Manufacture of machinery and } \\
\text { equipment } \\
34 \text { Manufacture of motor vehicles, } \\
\text { trailers and semi-trailers }\end{array}$ & $7.3 \%$ & $22.6 \%$ & 81 \\
\hline $\mathrm{F}$ & Construction & 45 Construction & $20.6 \%$ & $15.6 \%$ & 56 \\
\hline G & $\begin{array}{l}\text { Wholesale and } \\
\text { Retail Trade; } \\
\text { Repairs }\end{array}$ & $\begin{array}{l}51 \text { Wholesale trade and commission } \\
\text { trade, except of motor vehicles } \\
52 \text { Retail trade, except of motor } \\
\text { vehicles; repair of personal \& } \\
\text { household goods }\end{array}$ & $13.0 \%$ & $19.0 \%$ & 68 \\
\hline $\mathrm{H}$ & $\begin{array}{l}\text { Hotels and } \\
\text { Restaurants }\end{array}$ & 55 Hotels and restaurants & $3.1 \%$ & $9.5 \%$ & 34 \\
\hline 1 & $\begin{array}{l}\text { Transport, } \\
\text { Storage and } \\
\text { Communication }\end{array}$ & $\begin{array}{l}62 \text { Air transport } \\
64 \text { Post and telecommunications }\end{array}$ & $6.1 \%$ & $0.6 \%$ & 3 \\
\hline J & $\begin{array}{c}\text { Financial } \\
\text { Intermediation }\end{array}$ & $\begin{array}{l}65 \text { Financial intermediation, except } \\
\text { insurance and pension funding }\end{array}$ & $1.5 \%$ & $1.1 \%$ & 4 \\
\hline K & $\begin{array}{l}\text { Real Estate, } \\
\text { Renting and } \\
\text { Business } \\
\text { Activities }\end{array}$ & $\begin{array}{l}72 \text { Computer \& related activities } \\
74 \text { Other business activities } \\
\text { (excluding } 74.50 \text { and } 74.87 \text { ) }\end{array}$ & $24.8 \%$ & $21.2 \%$ & 76 \\
\hline M & Education & 80 Education & $2.9 \%$ & $0.8 \%$ & 3 \\
\hline N & $\begin{array}{l}\text { Health and } \\
\text { Social work }\end{array}$ & 85 Health and social work & $5.5 \%$ & $2.8 \%$ & 10 \\
\hline 0 & $\begin{array}{l}\text { Other } \\
\text { Community, } \\
\text { Social \& Personal } \\
\text { Service Activities }\end{array}$ & $\begin{array}{l}92 \text { Recreational, cultural and } \\
\text { sporting activities }\end{array}$ & $10.9 \%$ & $5.9 \%$ & 21 \\
\hline \multicolumn{5}{|c|}{ Total number of firms } & 358 \\
\hline
\end{tabular}

Table 1: Sample characteristics 


\begin{tabular}{ccccccc}
\hline & N & Minimum & Maximum & Total spend $\begin{array}{c}\text { Mean } \\
\text { average per } \\
\text { firm }\end{array}$ & Std. Deviation \\
\hline Total Design Spend (fk) & 358 & 0 & 39,647 & 92,827 & 260 & 2,191 \\
\hline Total Turnover $(\mathrm{fk})$ & 358 & 0 & 649,700 & $4,415,912$ & 12,334 & 54,712 \\
\hline
\end{tabular}

Table 2: Overall results

Average absolute investment

\begin{tabular}{crrrrr} 
& $\begin{array}{c}\text { Technical } \\
\text { design } \\
\text { (fK) }\end{array}$ & $\begin{array}{c}\text { User focused } \\
\text { design (fK) }\end{array}$ & $\begin{array}{r}\text { Promotional } \\
\text { design (fK) }\end{array}$ & $\begin{array}{c}\text { Identity } \\
\text { design (fK) }\end{array}$ & $\begin{array}{c}\text { Total average } \\
\text { design } \\
\text { investment (fK) }\end{array}$ \\
\hline Manufacturing & 698 & 17.3 & 34.2 & 11.5 & $\mathbf{7 6 1}$ \\
\hline Construction & 47 & 3 & 10.5 & 8.3 & $\mathbf{6 8 . 8}$ \\
\hline Retail and wholesale & 171 & 12.9 & 44 & 14.8 & $\mathbf{2 4 2 . 7}$ \\
\hline $\begin{array}{c}\text { Other business } \\
\text { services }\end{array}$ & 55 & 20.1 & 31.5 & 9.7 & $\mathbf{1 1 6 . 3}$ \\
\hline Whole sample & $\mathbf{2 1 1}$ & $\mathbf{1 1 . 6}$ & $\mathbf{2 8 . 4}$ & $\mathbf{9 . 6}$ & $\mathbf{2 6 0}$ \\
\hline
\end{tabular}

Table 3: Average investment in design

Average investment as a percentage of turnover

\begin{tabular}{ccccc} 
& $\begin{array}{c}\text { Technical } \\
\text { design \% }\end{array}$ & $\begin{array}{c}\text { User focused } \\
\text { design \% }\end{array}$ & $\begin{array}{c}\text { Promotional } \\
\text { design \% }\end{array}$ & $\begin{array}{c}\text { Identity design } \\
\text { \% }\end{array}$ \\
\hline Manufacturing & 2.28 & 0.37 & 0.80 & 0.19 \\
\hline Construction & 0.87 & 0.04 & 0.18 & 0.08 \\
\hline Retail and wholesale & 2.10 & 0.31 & 1.35 & 0.40 \\
\hline Other business services & 2.96 & 0.64 & 2.23 & 0.63 \\
\hline Whole sample & $\mathbf{1 . 9 8}$ & $\mathbf{0 . 3 5}$ & $\mathbf{1 . 2 7}$ & $\mathbf{0 . 3 6}$ \\
\hline
\end{tabular}

Table 4: Design investment as a percentage of turnover 


\begin{tabular}{|c|c|c|}
\hline & $\begin{array}{c}\text { In house } \\
\text { design } \\
\text { investment }\end{array}$ & $\begin{array}{l}\text { Outsourced } \\
\text { design } \\
\text { investment }\end{array}$ \\
\hline $\begin{array}{c}\text { Technical design } \\
\text { investment }\end{array}$ & $\mathrm{f} 67.6 \mathrm{~m}$ & f7.5m \\
\hline $\begin{array}{l}\text { Experiential design } \\
\text { investment (i.e. user } \\
\text { focused design + } \\
\text { promotional design + } \\
\text { identity design) }\end{array}$ & $\mathrm{f} 11.5 \mathrm{~m}$ & f6.1m \\
\hline
\end{tabular}

Figure 5: total in house vs. outsourced design investment for the whole sample

\begin{tabular}{|c|c|c|}
\hline & $\begin{array}{l}\text { In house } \\
\text { design } \\
\text { investment }\end{array}$ & $\begin{array}{l}\text { Outsourced } \\
\text { design } \\
\text { investment }\end{array}$ \\
\hline $\begin{array}{r}\text { Technical design } \\
\text { investment }\end{array}$ & $£ 190,000$ & $£ 21,000$ \\
\hline $\begin{array}{r}\text { Experiential design } \\
\text { investment (i.e. user } \\
\text { focused design + } \\
\text { promotional design + } \\
\text { identity design) }\end{array}$ & $£ 32,400$ & $£ 17,200$ \\
\hline
\end{tabular}

Figure 6: average in house vs. outsourced design investment

\begin{tabular}{|c|c|c|c|c|}
\hline \multirow{2}{*}{$\begin{array}{l}\text { Number of } \\
\text { employees }\end{array}$} & \multicolumn{2}{|c|}{$\begin{array}{l}\text { Design investment in the creation of } \\
\text { products and services }\end{array}$} & \multicolumn{2}{|c|}{$\begin{array}{c}\text { Design investment in the } \\
\text { commercialization of products and } \\
\text { services }\end{array}$} \\
\hline & $\begin{array}{l}\text { Technical design } \\
\text { investment }\end{array}$ & $\begin{array}{l}\text { User-focused } \\
\text { design } \\
\text { investment }\end{array}$ & $\begin{array}{l}\text { Promotional } \\
\text { design } \\
\text { investment }\end{array}$ & $\begin{array}{l}\text { Identity design } \\
\text { investment }\end{array}$ \\
\hline$>250$ & $5.24 \%$ & $0.04 \%$ & $0.87 \%$ & $0.42 \%$ \\
\hline $50-249$ & $1.89 \%$ & $0.34 \%$ & $1.12 \%$ & $0.21 \%$ \\
\hline $10-49$ & $1.76 \%$ & $0.37 \%$ & $1.22 \%$ & $0.39 \%$ \\
\hline$<10$ & $2.06 \%$ & $0.44 \%$ & $1.79 \%$ & $0.42 \%$ \\
\hline
\end{tabular}

Table 5: Average design spend as a percentage of turnover by category and size 
Design investment in the creation of products and services (technical and user-focused design)

\begin{tabular}{|c|c|c|c|}
\hline \multirow{2}{*}{$\begin{array}{r}\text { Design investment in the } \\
\text { commercialization of } \\
\text { products and services } \\
\text { (promotional and identity } \\
\text { design) }\end{array}$} & & NO & YES \\
\hline & NO & $15.4 \%$ & $5.6 \%$ \\
\hline & YES & $36.0 \%$ & $43.0 \%$ \\
\hline
\end{tabular}

Figure 7: Companies reporting zero design spend

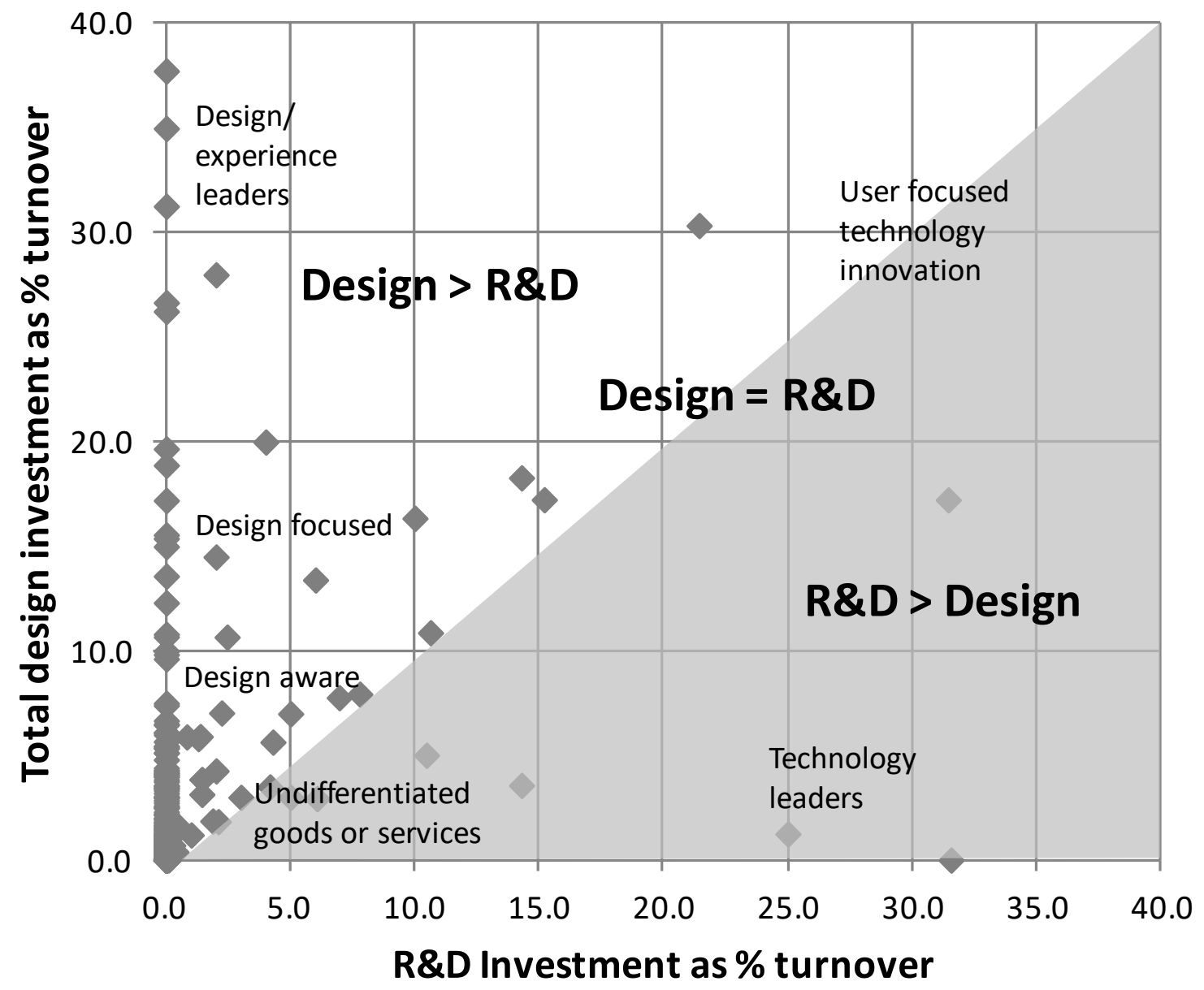

Figure 8: Design as \% Turnover vs. R\&D as \% Turnover 


\begin{tabular}{|c|c|c|c|c|c|c|c|c|c|c|c|c|c|c|c|c|}
\hline \multirow{3}{*}{$\begin{array}{l}\text { Self } \\
\text { reported } \\
\text { precision }\end{array}$} & \multicolumn{4}{|c|}{ Technical design } & \multicolumn{4}{|c|}{ User focused design } & \multicolumn{4}{|c|}{ Promotional design } & \multicolumn{4}{|c|}{ Identity design } \\
\hline & \multirow{2}{*}{ 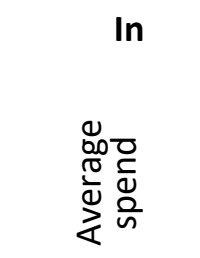 } & \multirow[b]{2}{*}{ 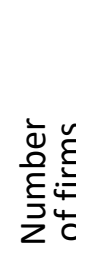 } & \multirow{2}{*}{ 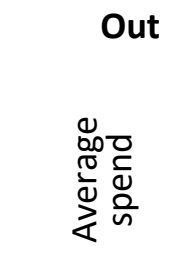 } & \multirow[b]{2}{*}{ 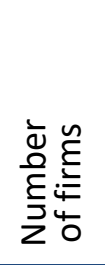 } & \multirow{2}{*}{ 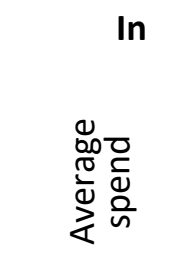 } & \multirow[b]{2}{*}{ 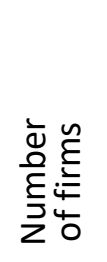 } & \multicolumn{2}{|c|}{ Out } & \multicolumn{2}{|l|}{ In } & \multicolumn{2}{|l|}{ Out } & \multicolumn{2}{|l|}{ In } & \multicolumn{2}{|l|}{ Out } \\
\hline & & & & & & & 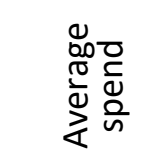 & 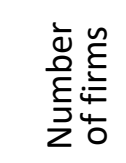 & 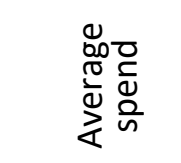 & 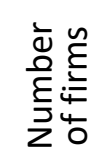 & 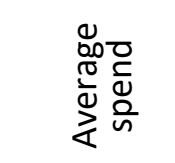 & 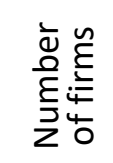 & 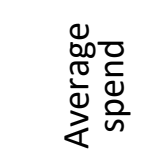 & 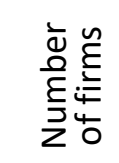 & 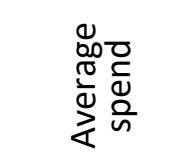 & 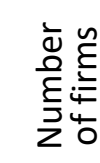 \\
\hline £1K & $£ 35,000$ & 63 & $£ 30,000$ & 56 & $£ 9,000$ & 57 & $£ 13,000$ & 51 & $£ 7,000$ & 105 & $£ 10,000$ & 109 & $£ 13,000$ & 71 & $£ 4,000$ & 115 \\
\hline f10K & $£ 369,000$ & 31 & $£ 60,000$ & 22 & $£ 49,000$ & 18 & $£ 24,000$ & 8 & $£ 110,000$ & 31 & $£ 41,000$ & 36 & $£ 39,000$ & 20 & $£ 25,000$ & 24 \\
\hline$£ 50 \mathrm{~K}$ & $£ 577,000$ & 11 & $£ 674,000$ & 6 & $£ 183,000$ & 3 & None & None & $£ 170,000$ & 8 & $£ 88,000$ & 5 & $£ 65,000$ & 2 & $£ 141,000$ & 3 \\
\hline$£ 100 K$ & $£ 4,332,000$ & 11 & $£ 500,000$ & 1 & $£ 433,000$ & 3 & None & None & $£ 225,000$ & 4 & $£ 643,000$ & 1 & None & None & None & None \\
\hline
\end{tabular}

Table 6: Self reported precision of estimates, with corresponding average spend in each category (not including companies with zero design spend in a category) 


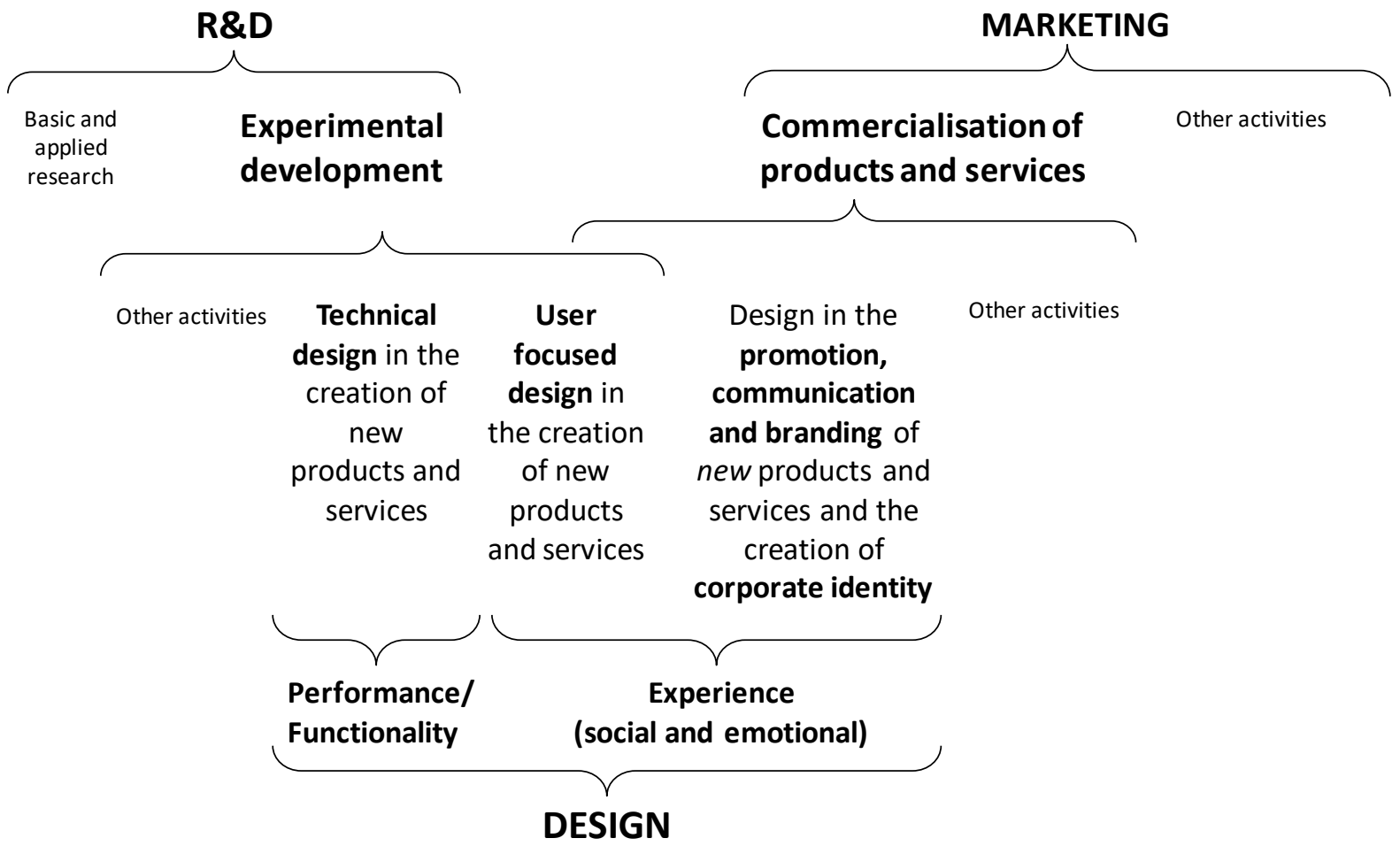

Figure 9: Revised conceptual framework - categories of design spend within the context of the firm 


\section{Appendix 1: Questionnaire}

\section{Survey of Design Spend in Firms}

Through this survey, we are aiming to understand how much UK firms spend on design. All data provided will be treated as strictly confidential and in accordance with the Data Protection Act and the professional standards of the Market Research Society. Neither you nor your company will be named in any public reports produced from this work.

\section{About You}

\begin{tabular}{|l|l|}
\hline Company Name & Type here \\
\hline Your name & Type here \\
\hline Job Title & Type here \\
\hline
\end{tabular}

\section{Estimates of design spend in your firm}

We will ask for your best estimates of design spend in different aspects of your business. This includes design spend in the creation of products and services, design spend in the selling of products and services and design spend in the branding/promotion of the company.

We realize that these values are not necessarily readily available in company accounts. Therefore, we are looking for your BEST ESTIMATES. Recognizing that this will be an estimate, we would also like you to indicate the precision of this estimate, ranging from to the nearest $f 1 K$, to the nearest $1100 K$. We would like your estimate to cover the LAST FINANCIAL YEAR. Specifically, we would like estimates on in-house spend and outsourced spend:

- In-house design spend: this should include design expenditure on work undertaken by any employee whose primary role is design in the areas described. For example, this might include the design of a circuit board, but not the cost of producing the circuit board. This might include the cost of designing a new brochure, but not the cost of printing the brochure.

- Outsourced design spend: this is the full cost of any design work commissioned to an external design supplier. In this case, we recognise that it might not be possible to separate the costs associated with design and with production."

We want to ask you about four different areas of design: Technical design of products and services; Design of the user experience for products and services; Design of promotional materials for specific products and services; Design to develop and promote your corporate identity. These will be explained as we proceed. 
Please provide your best estimates of design spend in your LAST FINANCIAL YEAR and tick the appropriate box to indicate how accurate you think your estimate is.

Wherever possible please try to include design costs (e.g. design of a circuit board or brochure) and exclude the costs of production (e.g. manufacturing the circuit board or printing the brochure).

2.1 Design spend - on technical design in the creation of products and services

How much do you spend in-house and outsourced on 'technical design' in the creation of new products and services? This includes design work typically associated with the 'inside' of a product that determines its functionality and performance. This might include costs associated with:

- Technical design of products: e.g. design of mechanical, electrical or software based elements. Designers might include mechanical designers, electronic designers, software designers, systems designers. Outputs would include production drawings, test specifications, prototypes, etc.

- Technical design of services: e.g. design of technology to enable services, such as IT systems. Designers might include IT designers, web-designers, software designers etc."

What is the precision of your estimates?

\begin{tabular}{|c|c|c|c|c|c|c|}
\hline & \multirow{2}{*}{$\begin{array}{l}\text { Estimate of } \\
\text { design spend }\end{array}$} & \multicolumn{5}{|c|}{$\begin{array}{l}\text { Precision of estimate (please tick as appropriate, to indicate the } \\
\text { relative precision of your estimate) }\end{array}$} \\
\hline & & $\begin{array}{l}\text { Within } \\
f 1 K\end{array}$ & $\begin{array}{l}\text { Within } \\
\text { f10K }\end{array}$ & $\begin{array}{l}\text { Within } \\
f 50 \mathrm{~K}\end{array}$ & $\begin{array}{l}\text { Within } \\
\text { f100K }\end{array}$ & $\begin{array}{c}\text { Can't } \\
\text { estimate }\end{array}$ \\
\hline In House & $f K$ & & & & & \\
\hline utsourced & $f K$ & & & & & \\
\hline
\end{tabular}

2.2 Design spend - on the user or customer experience in the design of products and services How much do you spend in-house and outsourced on the user or customer experience in the design of new products and services. This includes design work typically associated with the 'outside' of the product or service. This might include e.g. design of the aesthetics, ergonomics and interfaces of products or manuals and multi-media to support service delivery.

\begin{tabular}{|c|c|c|c|c|c|c|}
\hline & \multirow{2}{*}{$\begin{array}{l}\text { Estimate of } \\
\text { design spend }\end{array}$} & \multicolumn{5}{|c|}{$\begin{array}{l}\text { Precision of estimate (please tick as appropriate, to indicate the } \\
\text { relative precision of your estimate) }\end{array}$} \\
\hline & & $\begin{array}{l}\text { Within } \\
\text { f1K }\end{array}$ & $\begin{array}{l}\text { Within } \\
\text { f10K }\end{array}$ & $\begin{array}{l}\text { Within } \\
£ 50 \mathrm{~K}\end{array}$ & $\begin{array}{l}\text { Within } \\
\text { f100K }\end{array}$ & $\begin{array}{l}\text { Can't } \\
\text { estimate }\end{array}$ \\
\hline In House & fK & & & & & \\
\hline Outsourced & fK & & & & & \\
\hline
\end{tabular}


2.3 Design spend - on the delivery, promotion and communication of specific products and services

How much do you spend in-house and outsourced on the design of communications and promotions related to new products and services. This spend is specifically associated with individual products or product lines and might include design of advertisements, brochures, showrooms, exhibition stands, and point of sale materials.

\begin{tabular}{|c|c|c|c|c|c|c|}
\hline & \multirow{2}{*}{$\begin{array}{l}\text { Estimate of } \\
\text { design spend }\end{array}$} & \multicolumn{5}{|c|}{$\begin{array}{l}\text { Precision of estimate (please tick as appropriate, to indicate the } \\
\text { relative precision of your estimate) }\end{array}$} \\
\hline & & $\begin{array}{l}\text { Within } \\
£ 1 K\end{array}$ & $\begin{array}{l}\text { Within } \\
\text { f10K }\end{array}$ & $\begin{array}{l}\text { Within } \\
£ 50 K\end{array}$ & $\begin{array}{l}\text { Within } \\
\text { f100K }\end{array}$ & $\begin{array}{c}\text { Can't } \\
\text { estimate }\end{array}$ \\
\hline In House & fK & & & & & \\
\hline Outsourced & fK & & & & & \\
\hline
\end{tabular}

2.4 Design spend - on the creation, communication and promotion of the corporate identity How much do you spend in-house and outsourced on the design of brands and identity at a business or corporate level. This spend might not be associated with any specific products or product lines. This might include the design of logos, corporate identity, business websites, uniforms, business colour schemes.

\begin{tabular}{|c|c|c|c|c|c|c|}
\hline & \multirow{2}{*}{$\begin{array}{l}\text { Estimate of } \\
\text { design spend }\end{array}$} & \multicolumn{5}{|c|}{$\begin{array}{c}\text { Precision of estimate (please tick as appropriate, to indicate the } \\
\text { relative precision of your estimate) }\end{array}$} \\
\hline & & $\begin{array}{l}\text { Within } \\
\text { f1K }\end{array}$ & $\begin{array}{l}\text { Within } \\
\text { f10K }\end{array}$ & $\begin{array}{l}\text { Within } \\
\text { f50K }\end{array}$ & $\begin{array}{l}\text { Within } \\
\text { f100K }\end{array}$ & $\begin{array}{c}\text { Can't } \\
\text { estimate }\end{array}$ \\
\hline In House & fK & & & & & \\
\hline Outsourced & fK & & & & & \\
\hline
\end{tabular}

2.5 Did you have any difficulties in providing these estimates?
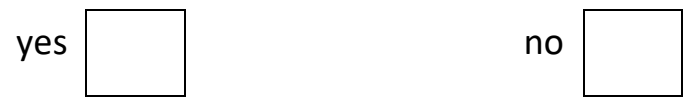

If yes, please explain the reasons below 


\section{The nature of your business}

Compared to others in your industry, where would you place your business on a scale of 1 to 5 in terms of ...

a) Production or service volume: where one indicates the business is a high volume producer/provider or high throughput services provider and five indicates you provide one-off or very low volume products or bespoke services

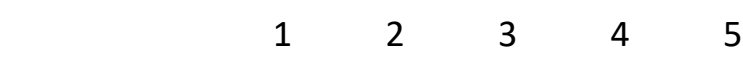

high volume $\quad \square \quad \square \quad \square \quad \square \quad \square \quad$ one-off

b) Price: where one indicates the competitive success of your business's products or services is wholly dependent on price and five indicates that success does not depend at all on price

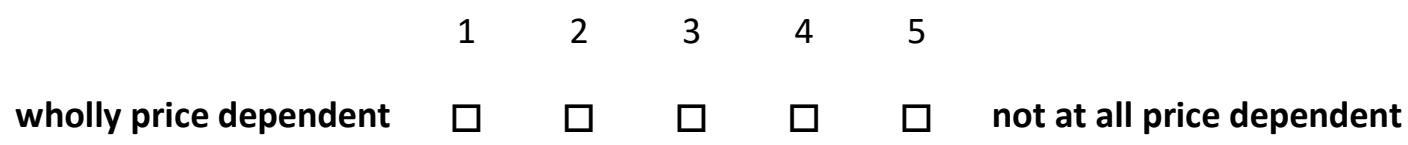

c) Quality: where one indicates the business competes in a market for standard or basic quality products or services and five indicates the business competes in a market for premium quality products or services

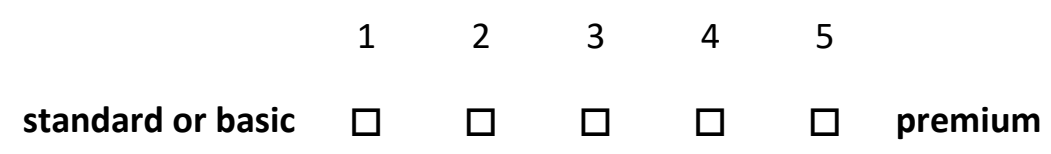

\section{Company data}

\begin{tabular}{|l|l|}
\hline $\begin{array}{l}\text { What are your organisation's main products and services? } \\
\text { (please write in descriptions or provide Standard Industrial } \\
\text { Classification codes) }\end{array}$ & Type here \\
\hline Turnover in the last financial year & fK \\
\hline Number of employees (excluding casuals) & No. \\
\hline Do you claim R\&D Tax Credits? & Yes/No \\
\hline R\&D spend in the last financial year & fK \\
\hline Approximate number of designers employed & No. \\
\hline
\end{tabular}

